\title{
Values Education Practices in Preschool: The Case of Turkey and the United States
}

\author{
Emin Tamer Yenen * \\ Department of Educational Sciences, Faculty of Education, Nevşehir Hacı Bektaş Veli \\ University, Nevşehir, Turkey \\ ORCID: 0000-0003-2359-3518 \\ Perihan Ulucan \\ Department of Educational Sciences, Faculty of Education, Nevşehir Hacı Bektaş Veli \\ University, Nevşehir, Turkey \\ ORCID: 0000-0003-4778-1804
}

Article history

Received:

15.01.2021

Received in revised form: 28.04.2021

Accepted:

05.05.2021

Key words:

Preschool,

Early childhood education,

Preschool education

curriculum,

Values education,

Preschool teachers
In this study, the aim is to determine national and universal values that are tried to be taught to children in pre-school education institutions of different cultures and to compare programs and practices in the context of value education within the framework of teachers' views. Case study, one of the qualitative research methods, was used in the study. In the study, criterion and convenience sampling methods, one of the purposive sampling methods, were used in determining the study group. In this context, the study group of the research consisted of 52 pre-school teachers who participated in the study voluntarily from Turkey and the United States, Ohio. In the study, semi-structured interview form was used as the data collection tool. The data of the study was analyzed by content analysis method. The results show that values education cannot be provided only through the integration of values in the curriculum, and that value transfer is a sophisticated process involving many disciplines. It is understood from the findings that there are significant differences in value perception as well as differences in practice in both countries. For example, in both countries the priority national values were found to be different. Although there are similarities in the methods and techniques used in values education practices in both countries, it was concluded that in terms of assessment methods teachers from Ohio were able to employ more diverse methods and observe their students better. In addition, teachers from Ohio do not experience as many problems as Turkish teachers and are solution-oriented in values education practices.

\section{Introduction}

Society is a living and changing system. It is the culture, traditions and values that unite, maintain and sustain society. A sustainable society can stand by transferring its culture,

\footnotetext{
* Correspondency: tamer-yenen@hotmail.com
} 
traditions and values to the next generations (Sapsağlam, 2016a). The education of values is a process that starts with the family and then continues with the social environment. In order to learn the unique values of a society as well as universal values and transfer them to future generations, there must be experiences involving values. The starting point of this experience is early childhood (Uzun \& Köse, 2017).

Throughout human history, scientists and researchers have made numerous and different definitions of the concept of values. Rokeach and Regan (1980) define values as permanent beliefs which determine whether a specific behavior or specific situation can be considered to be personally or socially acceptable. According to Schwartz, Caprara and Vecchione (2010) the concept of values is the beliefs which people strive to acquire and make efforts to have, and which shape our choices or the evaluation of behaviour and choices. Some educators have defined values as a set of ideas, norms and aims that are accepted by a community, or patterns of behavior developed by the individual to participate in the community (Cooper, 2014; Ryan, Bohlin \& McDonnell, 1999; Titus, 1994). In the most general sense, values are our judgments about what is good and evil. Rather than one's own wishes and desires, they are certain norms and systematic ideas that enable the individual to interact with society and the social environment (Veugelers \& Vedder, 2003).

Values are considered phenomena that are teachable and learnable. However, in the 21st century, the transfer of values to the next generation has been a more difficult process than it used to be in the previous years. Many values that are adopted and supported by society have been transferred through living, and today this experience is not enough. School and family should struggle and take responsibility more because children are exposed to a wide variety of stimuli and form their system of values by being influenced by many factors. It is a social task not to leave the development of the values of children to coincidence and uncontrolled mechanisms (Gömleksiz, 2007).

Values education focuses on two purposes. The first one stresses that people, especially young people, pursue an ethical, happy and satisfying life. The other one aims to provide a social benefit (Akbaş, 2009; Kirschenbaum, 2000). Hence, it can be said that values are related both to the individual's own internal dynamics, in other words, self and personality, and are concerned with the whole society's benefit at the highest level. When examined individually or socially, values that are directly involved in human life and shaping it have been the subject of research for centuries in all areas of education. One area of interest and study in values research is related to how values are gained and acquired. Values, which are the basic structures that shape a society's life, need to be transferred from generation to generation. No human being is born with certain values, so, for this reason, values are transferred in planned and unplanned ways, in different forms by individuals or institutions (Yeşil \& Aydın, 2007).

The education system of a society and the institutions and organizations within this system are the important units that display the values of that society. As a social institution, the school provides the transfer of social, cultural, universal and social values to children through educational programs. The school should not only ensure academic achievement, but also enable a child to learn about the culture and values of the specific society (Sapsağlam, 2016, b). It is possible to educate qualified and moral individuals in a society with the education of values given in schools (Aspin, 2000; Halstead \& Pike, 2006). Dewey (2013) stated that schools play an important role in the moral development of children and should provide them with opportunities to turn these values into behavior. Schools that reflect ethical values in 
learning environments contribute to social transformation (Cooper, 2014). Furthermore, schools are important tools of social control since they acquire the values and norms accepted by the society within the framework of a specific plan and monitor whether appropriate behaviors are exhibited (Erden, 1998). The value-added function of the school is realized through education programs and teachers' implementing these programs.

\section{Values Education in The Preschool Context}

One key research area is the question of when values education should start. Many educators and experts focus on early childhood. Values develop by benefiting from many sources and the first bases of information about values are formed in this period (Balat \& Dağal, 2009; Ogelman \& Sarıkaya, 2015). The preschool period is a critical period in which the physical, social, emotional, cognitive, psycho-motor, language and moral development of a child is the fastest and covers the age range up to the age of seven (Hildebrandt \& Zan, 2008, Kohlberg, 1971; Piaget, 2002). The experiences of the child during this period have a significant effect on his/her subsequent social and academic life, behavior and thinking processes and what kind of person he/she will become (Sapsağlam, 2016a). The experiences that the child lives from birth to age seven play a determinant role in his/her development. The presence of the child in an environment where he/she can interact with others and the environment and which supports his/her development is as important as his/her sufficient nutrition (AÇEV, 2007).

Child development is a process that has its own dynamics, and each developmental stage is shaped on the previous step. Pre-school education starting from the birth of the child including all the experiences until primary school is a planned and programmed process that improves moral and cultural values, emotional development, perceived capacity and problem solving ability and also plays an important role in creativity and gaining self-expression (Başal, 2012; Pagani, Jalbert \& Girard, 2005; Ural \& Ramazan, 2007). The child should be closely watched during this period and the social values that will provide the formation of his/her character should be taught, because it is a social responsibility and even an obligation (Walker et al., 2012). If this education is ignored or if it is given unconsciously and in an unplanned way, it makes the whole life of the child more difficult, rather than making it easier. The purpose of education should be to make life easier, rather than making it more difficult. When preparing a child for adult life, the child must become an individual who is compatible with himself/herself and with his/her environment, realize him/herself, form his/her personality, and should gain attitudes and social values that are a sign of a positive person (Oktay, 1999). With the globalization process, in societies which race, language, religion, color, worldviews and lifestyles are different, children need to discover how to live without harming the rights and freedoms of others and achieve social unity.

Children who cannot develop the social and emotional skills needed to start school cannot meet the expectations that the school has for them. Such children especially have problems making friends, are inadequate in terms of being members of society and lack the abilities to live in harmony with others. For this reason, these children may have negative and devastating effects on other children involuntarily (Walker \& Golly, 1999). A lot of conducted research supports this view. It has been observed that children in the preschool years who lacked self-control, could not adequately express their feelings, and exhibited aggressive and incompatible behaviors in their relationships, experienced problems in adapting to social life not only during their early school years but also during adolescence, youth, adulthood and at old ages (Egeland, Yates, Appleyard \& Van Dulmen, 2002). The 
education of healthy individuals who can freely state their emotions and thoughts, who are entrepreneurs and researchers, who can provide self-control, who are respectful for the rights of others, who have the ability to use their skills and who have cultural values which are requirements of a contemporary and democratic society can be accomplished by focusing on the education of children in the pre-school period (Aral, Kandır \& Can Yaşar, 2003).

International organizations do emphasize the importance of pre-school education. In the report, "Starting Strong," the Organisation for Economic Co-operation and Development (OECD) presents and uses all indicators regarding early childhood education and makes an international comparison in this regard. They contend that the early years of life provide a basis of skill development and learning for the future. The report states that investments for high-quality early childhood education and care, and proper transitions between various steps of early education are key features for children's long-term learning and development (OECD, 2017). In addition, the results of several small-scale studies conducted by various researchers document that pre-primary education contributes to better education, professional and social outcomes for disadvantaged children in the long term as well as children with normal opportunities and developmental characteristics and is cost-effective. However, the results of large-scale, long-term studies also indicate that early childhood education positively affects the economic success and health status of individuals over the following years (Melhuish, 2011; Reynolds et al., 2011).

Teachers are another element that is as important as the program in values education in preschool education institutions (Yazar \& Erkuş, p. 198). Because the teacher is the most effective person in the implementation of the program and in the students' development in schools (Şen, 2011; Weist, 1998), teachers also have the greatest role in teaching attitudes, behaviors and values. The pre-school teacher is the first person with whom the child is in contact after he/she leaves the family for the first time. When he/she starts school, the child takes his/her teacher as a model instead of his/her family members and tries to identify himself/herself with him/her (Yavuzer, 2012). Since teachers have a central position in values education, children are influenced by their value choices and love values with their teachers (Halstead \& Taylor, 2000).

Teachers' value judgments and behaviors, and the methods and techniques they use, may affect students' learning styles, behaviors and conception of values (Weist, 1998). Teachers need to be able to accurately reflect values, create educational environments in which positive experiences are exhibited, and perform different activities both in and outside the classroom by using various methods (Uzun \& Köse, 2017). In this context, in-class activities, experiences and opinions of teachers towards values education are of particular importance (Y1ldırım, 2009).

When the related literature is evaluated in general, it can be said that values education concerns all humanity in the universal dimension and that the most effective and productive period in the acquisition of values is pre-school education. For this reason, teachers working in pre-school education institutions have a great responsibility in terms of providing and supporting children's social and emotional development as well as cognitive development. This support can be provided by proper planning and implementation of the teaching of values. 


\section{Values in Ohio and Turkey in the Context of Pre-School Education}

Every state in the United States is implementing its own program. In the State of Ohio where the study was conducted, the early childhood education institutes regulate their programs according to the common standards. These standards were widened by the joint work of Ohio Department of Education and public health organizations such as Ohio Department of Job and Family Services, Ohio Department of Health, and were acknowledged by all institutions that provide children care and education services who are in the period from birth till kindergarten as of 9th of October, 2012. Even though preschool institutions adopt a different program, they regulate their program according to these standards (Early Childhood Ohio, 2017).

The United States is the country where the concept of values education emerged, and it is where programs are most applied. Many character education organizations and programs try to promote basic values (Acat \& Aslan, 2010). In the United States, early childhood education programs are not centralized though as has been mentioned earlier on. Each state constructs and implements its own educational standards. However, there is an organization named National Association for the Education of Young Children (NAEYC) which has been working on establishing common standards across the country. NAEYC is a not-for-profit private organization, and not funded by the government either. It is a professional membership organization that has recommended standards for the field. It provides accreditation for higher education programs that train teachers and accreditation for child care programs. Some states may require universities to seek NAEYC accreditation for their teacher licensure programs. Many child care programs seek accreditation because it is a way to provide high-quality education to prospective parents. This organization provides a unity between research, policies, and practices to encourage all children aged 0-8 to receive a high-quality education. It supports the development of various dynamics of the early childhood profession and supports those who serve or educate children and all those who work for them.

In addition, in the United States there are the states' own approaches to early childhood education. In the state of Ohio, to illustrate, as one study area of the present research, the Department of Education has named its vision of early childhood education as, "All children are valuable, healthy and happy." They refer to the same unit goals as providing children with high-quality education and care and environment, providing services and support for a wide range of healthy development, and providing families with meaningful community and parent support (Early Childhood Ohio, 2017).

In 2012, the state of Ohio reassessed and broadened Ohio early childhood education standards as a result of an intensive workshop of experts from all the stakeholders that will support and serve them from birth to the age of five. Those standards include five fields, which are:

- Social and Emotional Development

- Physical Well-being and Motor Development

- Approaches Toward Learning

- Language and Literacy Development Cognition and General Knowledge

In the interpretation of the standards, it is envisaged that the standards are reflected in the curriculum as a holistic approach, covering cognitive, emotional and psychomotor domains. In other words, Ohio early childhood education standards include universal values such as respect, responsibility, justice, and security as well as the knowledge and skills required to be a society-friendly individual (Ohio Department of Education, 2017). 
In preschool education in Turkey, a single and a joint program prepared by the Ministry of National Education is implemented. The Ministry of National Education 2013 Preschool Education Program is based on the "Preschool Education Program for Children of 36-72 Months", which was implemented to be developed in 2006. Within the scope of Empowering Preschool Education project, status analyses were made, as a result of feedback from various studies and implementations at the national and international level, a program development study was conducted once again in 2012 and 2013 school years. The program aims to promote healthy growth and self-care of children and to prepare them for elementary school by supporting all developmental areas of children. Thus, the program assists in children's gaining of rich learning experiences (MNE, 2013).

Values education practice in Turkey is based on an international project under the name of the "Living Values Education Program (LVEP)" supported by UNESCO and prepared for the 50th anniversary celebration of the United Nations in 1995 (Cihan, 2010). In this educational project, the aim was to instill universal values such as democracy, justice and freedom in students by adopting activity-based approaches.

A joint program prepared by the Ministry of Education (MEB) in pre-school education is used in Turkey. Within the framework of the "Project for Strengthening Pre-School Education" studies, various regulations were made in the pre-school education program in 2012 and pilot applications started in the same year. In the academic year 2013-2014, it spread all over the country. In this program, the developmental characteristics of children are divided into three age groups, 36-48 months, 48-60 months, and 60-72 months. It is designed with the expectation that it will be a multifaceted developmental program with supporting and preventive dimensions for children's development. The aim of the program, based on healthy growing-up, is to gain rich learning experiences that will bring children to the top of their motor, social and emotional, language and cognitive development areas (MEB, 2013).

The aims and duties of pre-school education, in accordance with the general objectives and basic principles of the national education are then as follows:

- To ensure that children gain physical, mental, and emotional development and good habits,

- To prepare them for elementary school,

- To create a common upbringing environment for children from conditions of unfavorable surroundings and families,

- To ensure that children speak Turkish language correctly and well (MEB, 2013, p. 10).

In Turkey as in the whole world, the importance of early childhood education is increasingly better understood. However, the socio-economic and political changes in the country which affect this area, have delayed the work of renewal and development. Research on pre-school children, their parents and teachers and values education needs to be improved and expanded in Turkey (Ogelman \& Sarıkaya, 2015). Adding of values to pre-school children requires a well-organized structure considering related developmental characteristics. The implicit provision of values education in the pre-school curriculum imposes a great responsibility on teachers in teaching these values. Teacher's value preferences, attitudes and behaviors, knowledge of methods and techniques and classroom performance are of great importance in achieving the goals of values education (Uzun \& Köse, 2017). In this study, the aim was to determine national and universal values that are introduced to children in pre-school 
education institutions of different cultures and to compare programs and practices in the context of values education within the framework of teachers' views.

Examining values education practices in different countries in early childhood education and revealing the opinions of teachers about values education will guide early childhood education studies and new projects as well as research to be done in this field. Determining how values education is applied by pre-school teachers in pre-school education institutions, identifying the problems encountered during the teaching process and presenting suggestions for the development of the applications will contribute to the field. In addition, the findings of this study will shed light on the values education dimension in the development process of the pre-school curriculum.

In this regard, the main aim of the study is to determine national and universal values that are tried to be taught to children in pre-school education institutions of Turkey and Ohio and to compare programs and practices in the context of value education within the framework of teachers' views. Within the general aim of the study, the following sub-problems were also addressed:

According to the views of pre-school teachers in Turkey and Ohio:

(1) What are the national and universal values students are expected to gain?

(2) How do teachers create content-activities while adding values to their students?

(3) What methods and techniques do teachers use in the process of adding values?

(4) As a result of these practices, what changes in student behavior are observed?

(5) How do teachers evaluate their students?

(6) What kind of difficulties do teachers experience in the process of using values education practices?

(7) What are the recommendations for development of practices for pre-school teachers in Turkey?

\section{Method}

\section{Research Model}

Case study, one of the qualitative research methods, was used in the study. The case study is defined as the empirical investigation of a contemporary phenomenon in the real-life context, especially when the context and the boundaries of the cases are not certain (Yin, 2017). According to Creswell (2007) case study is a qualitative research approach that examines one or several situations in depth with data collection tools (observations, interviews, audio-visuals, documents, reports) containing multiple sources and defines situations and themes depending on the situation. The case in this study is to examine what the values in preschool curricula in Turkey and Ohio are and how these values are given by teachers.

\section{Study Group}

In the study, convenience sampling method, one of the purposive sampling methods, was used in determining the study group. Convenience sampling method was also used in the study since the participants were voluntary and were selected from the regions where the researchers worked. In this context, the study group consisted of 52 pre-school teachers who participated in the study voluntarily from Turkey and the state of Ohio in the United States. 
Participants were selected from six kindergartens in Turkey (Nevsehir) and five kindergartens in Ohio (Cincinnati). Demographic information about the participants is summarized in Table 1 .

Table 1. Demographic Information About the Participants

\begin{tabular}{|c|c|c|c|}
\hline & Demographic Information & Turkey & Ohio \\
\hline & & f & f \\
\hline \multirow{2}{*}{ Gender } & Female & 24 & 25 \\
\hline & Male & 2 & 1 \\
\hline \multirow{5}{*}{ Education } & High school & 1 & - \\
\hline & Associate Degree & 1 & 3 \\
\hline & License & 24 & 21 \\
\hline & M.Sc. & 1 & 2 \\
\hline & + Certificate programs & 1 & 6 \\
\hline \multirow{7}{*}{$\begin{array}{l}\text { Professional } \\
\text { Experience }\end{array}$} & Less than a year & 1 & 1 \\
\hline & $1-5$ years & 5 & 7 \\
\hline & $5-10$ years & 7 & 5 \\
\hline & $10-15$ years & 7 & 1 \\
\hline & $15-20$ years & 3 & 3 \\
\hline & More than 20 years & 3 & 9 \\
\hline & Total & 26 & 26 \\
\hline
\end{tabular}

As can be seen from the table, most of the participants in both countries are female and graduate participants. Most of the participants in Turkey are between 5-15 years of professional experience. The majority of teachers in Ohio are in the group of 20 and over.

\section{Data Collection Tool}

In the study, a semi-structured interview form was used as the data collection tool. The form developed by the researchers consists of two parts. The first part contains the demographic information of the participants; the second part consists of eight open-ended questions that reveal the participants' views on values education practices in pre-school education. In the process of creating the interview form, pre-school curricula of both countries and literature about values education were examined and expert opinions were consulted. The final form of the data collection tool was made by making the necessary corrections (one question was removed from the interview form and one question was corrected in terms of content) in line with the opinions of two experts in the field of curriculum and instruction and two experts in the field of pre-school teaching. After the interview form was prepared, a pilot study was conducted with two pre-school teachers. Both researchers evaluated the data obtained from the pre-application, examined the consistency of the created themes and codes, and sought to prevent biased evaluations.

\section{Data Collection}

The research data were collected from 52 kindergarten teachers working in six schools in the city center of Nevşehir, Turkey and in five schools in Cincinnati, Ohio during the 20172018 academic year. The data were collected from the participating teachers in three different 
ways. 17 teachers were interviewed face-to-face and the interviews lasted an average of 25 minutes. 15 teachers completed the open-ended questionnaire in writing and 20 teachers expressed their opinions through oral conversation.

\section{Data Analysis}

The data of the study were analyzed by the content analysis method. The concepts extracted from the interview data were divided into themes and codes and presented in tables using the frequency technique. Firstly, interpretation of the teachers' views under the themes was examined by considering whether the differences in the cultural care differed within the framework of the identified sub-problems. In order to increase the internal reliability and credibility of the research findings, quotations were taken from the teachers' opinions. Turkish participants were expressed as TK1, TK2,.., participants from Ohio were indicated as OK1, $\mathrm{OK} 2, \ldots$ In the study, also, in order to ensure the internal and external reliability of the results obtained from the interviews, the evidence regarding the authenticity of the findings, similar processes' being consistent with each other, the validity of the results in similar environments, the data's being collected by an objective approach and demonstrating that the manifested results presented objectively were all attempted to be assured

\section{Limitations}

Research findings are limited to data obtained from the study group determined in Turkey and US-Ohio in the 2017-2018 academic year.

\section{Results}

\section{Findings on National Values}

The findings on the national values expected to be gained according to the opinions of the preschool teachers are shown in Table 2.

Table 2. National Values in the Context of Pre-School in Turkey and Ohio

\begin{tabular}{llll}
\hline Turkey & Ohio & $\mathrm{f}$ \\
\hline Palues & $\mathrm{f}$ & Values & 14 \\
Natriotism & 24 & Autonomy & 10 \\
Kemalism (Ataturkism) & 18 & Social Life Rules & 9 \\
Cultural Values & 10 & Respect & 9 \\
Tolerance & 8 & Kindness & 5 \\
Love & 6 & Patriotism & 4 \\
Respect & 5 & Empathy & 3 \\
Honesty & 5 & Peace & 3 \\
National Peace & 4 & Accepting Differences & 3 \\
Solidarity & 3 & Freedom & 2 \\
Sharing & 2 & Sharing & 2 \\
Being a Good Person & 2 & Kindliness & 2 \\
\hline
\end{tabular}

According to the opinions of the teachers who participated in the research from Turkey, national values can be listed as patriotism, national unity, Kemalism, cultural values, tolerance, love, respect, honesty, national peace, solidarity, sharing, and being a good person. Almost all of the teachers see patriotism as the number one national value. Under the theme of patriotism, it is understood that teachers talk about love of homeland, nation and flag and 
respect for our national anthem.

"Love for the homeland, love for Atatürk, being fair, respect, the importance of rules in the protection of social order, our cultural values..." (TK4)

"Primary things done for the love for the nation and the society, and for being a good person." (TK13)

14 of the Ohio teachers see autonomy as the first national value. According to the analysis results codes such as personal liability, self-confidence, self-control, self-care skills, problemsolving skills, self-defense skills, self-realization and coping with difficulties come to light under the theme of autonomy. This is followed by social life rules, respect, kindness, patriotism, empathy, peace, accepting differences, freedom, sharing, kindliness and hard work. Some of the teachers' views are presented below:

"National values... I don't personally make a distinction between them. We have respect for the government, for the flag, and as you know this kind of thing confront us as national values. Respect for people and self-respect come to light for children and I personally think that there are no large differences between these in the aspect of national and universal values, especially for children who take pre-school education. Because everything starts with love, respect and peace. I think this is important." (OK8)

\section{Universal Values According to Teacher Views}

The findings regarding universal values that are expected to be gained according to the opinions of preschool teachers are presented in Table 3.

Table 3. Universal Values in the Context of Pre-School in Turkey and Ohio

\begin{tabular}{llll}
\hline Turkey & f & Ohio & f \\
Values & 20 & Values & 19 \\
\hline Respect & 12 & Kindness & 15 \\
Love & 9 & Peace & 10 \\
Peace & 8 & Justice / Equality & 9 \\
Tolerance & 6 & Socially Acceptable Behaviors & 5 \\
Cooperation & 6 & Love & 5 \\
Nature and Environment & 5 & Empathy & 5 \\
Responsibility & 4 & Patience & 5 \\
Accuracy & 4 & Cooperation & 3 \\
Sharing & 2 & Happiness & 3 \\
Justice & 2 & Curiosity & 3 \\
Etiquette & 2 & Goodness & 2 \\
Patience & 1 & Nature & 2 \\
Empathy & 1 & Honesty & 2 \\
Self-reliance & 1 & Modesty & 1 \\
Cleanliness & Friendship & 1 \\
Awareness & 1 & Sharing & 1 \\
Kindness & 1 & Work ethic & 1 \\
Moral values & 1 & Courage & 1 \\
Saving & 1 & & 5 \\
\hline
\end{tabular}

The teachers participating in the research from Turkey see respect ( $f=20$ ) as the first universal value. This is followed by the value of love $(f=12)$ and peace $(f=9)$. Some of these values are as follows: tolerance, cooperation, nature and environment and responsibility respectively. 
"I can say respect for differences, respect for elders, not wasting resources, participating in production, protecting nature, tolerance." (TK21)

Respect $(f=19)$ took the first place according to the opinions of the participating teachers in Ohio. This is followed by kindness, peace, justice / equality, socially acceptable behavior, love, empathy and patience. Sample excerpts reflecting teachers' views are given below:

"Treat others the way you want to see. To be able to behave appropriately in social situations. First of all, to train self-confident individuals, to make the students defend themselves and to prepare them in the most comfortable environment to reach their potentials, that is, to help them reach their potential cognitively." (OK11)

"I think happiness is a universal value. And I think it's probably more than anything. We try to communicate with children gently, which makes them never underestimate or feel shy. We try to be polite in everything we do and I think people all over the world respond positively to such an approach." (OK23)

\section{Findings Related to Content-Activity}

The themes formed for content-activities according to the participants' views are given in Table 4.

Table 4. Themes Related to Content-Activity

\begin{tabular}{llll}
\hline Turkey & $\mathrm{f}$ & Ohio & $\mathrm{f}$ \\
\hline Forming program-based content & 22 & $\begin{array}{l}\text { Lesson plan in accordance with common } \\
\text { standards }\end{array}$ & 17 \\
Special days and weeks & 11 & Special days and weeks & 10 \\
Art activities & 8 & Art activities & 9 \\
Music activities & 6 & Music activities & 9 \\
Game activities & 5 & Game activities & 7 \\
Nature activities & 5 & Science and experiment activities & 4 \\
Activities with family participation & 4 & Activities with family participation & 4 \\
Animation and drama activities & 2 & Animation and drama activities & 3 \\
Cognitive activities & 2 & Cognitive activities & 3 \\
Excursions & 1 & Individual events & 2 \\
& & Social interactive activities & 2 \\
& & Home visits & 2 \\
& & Nature trips and activities & 2 \\
\hline
\end{tabular}

According to the views of most pre-school teachers in Turkey, content regarding values education is based on the pre-school education programs and organized by activities such as special days and weeks, art, music, games and nature activities respectively. When Table 4 is examined, it is seen that there are similarities between the views of teachers from both countries. According to the views of teachers in Ohio, content for values education is formed in accordance with the common standards set by the state and similar activities are generally held. Some of the teachers' views on content-activity are:

"I usually deal with specific days and weeks. I teach poetry and songs by memorizing, drama work and art activities or watching a short video on the subject." (TK1)

"Most values are something we naturally work on in class. We always talk to the children about the rules, about their feelings, about fulfilling their responsibilities, and so on. Some values are also intertwined in the Ohio Early Learning and Development Standards. We organize our 
lesson plans in the same direction as working in social settings and following other safety rules in the school." (OK3)

"We're talking about all the holidays. We're not just focusing on a holiday. We focus on Christmas, Hanukkah and Kwanzaa. We will even integrate the winter solstice into our subjects. We recently performed Diwali festival. We do this kind of thing. We teach a value in doing this. So, we can be different or we can be the same, both situations are suitable for us..." (OK10)

\section{Findings on Methods and Techniques}

According to the opinions of the kindergarten teachers who participated in the study, the methods and techniques used in the dimension of values education are shown in Table 5.

Table 5. Methods and Techniques Used in Values Education in the Context of Pre-School in Turkey and Ohio

\begin{tabular}{|c|c|c|c|c|c|}
\hline Method & Turkey & $\mathrm{f}$ & Method & Ohio & $\mathrm{f}$ \\
\hline Discourse & $\begin{array}{l}\text { Lecture, reading, } \\
\text { improvisation, } \\
\text { question-answer }\end{array}$ & 19 & Discussion & $\begin{array}{l}\text { Guidance, small group, large group } \\
\text { discussion, circle time, individual } \\
\text { work, dialogue, peer guidance }\end{array}$ & 21 \\
\hline Discussion & $\begin{array}{l}\text { 6-hat technique, chat, } \\
\text { big group discussion, } \\
\text { brainstorming }\end{array}$ & 14 & Case study & $\begin{array}{l}\text { Dramatic play, cooperative learning, } \\
\text { role playing }\end{array}$ & 18 \\
\hline Case study & $\begin{array}{l}\text { Drama, } \\
\text { animation }\end{array}$ & 10 & $\begin{array}{l}\text { Problem } \\
\text { solving }\end{array}$ & $\begin{array}{l}\text { Puzzle, block building, creative } \\
\text { thinking, reflective thinking, open- } \\
\text { ended art, research }\end{array}$ & 15 \\
\hline Demonstration & $\begin{array}{l}\text { Being model, showing } \\
\text { and making }\end{array}$ & 5 & Demonstration & $\begin{array}{l}\text { Being role models, showing and } \\
\text { making }\end{array}$ & 12 \\
\hline $\begin{array}{l}\text { Problem } \\
\text { solving }\end{array}$ & Creative thinking & 4 & Discourse & Reading books, repetition & 10 \\
\hline $\begin{array}{l}\text { Out-of-class } \\
\text { teaching } \\
\text { activities }\end{array}$ & $\begin{array}{l}\text { Family visits, } \\
\text { observation, excursion }\end{array}$ & 3 & $\begin{array}{l}\text { Out-of-class } \\
\text { teaching } \\
\text { activities }\end{array}$ & Family visits, observation, excursion & 7 \\
\hline
\end{tabular}

According to the opinions of teachers participating in research from Turkey, the most widely used method is discourse ( $f=19$ ) in values education. Other methods used are discussion, case study, demonstration, problem solving and out-of-class teaching activities.

"I ask them more questions about the subject-both what they think and what they know. I think this is all about what by myself I can teach them. Then, if there's anything they know wrong, I'll correct it and tell them theright thing." (TK5)

According to the views of teachers in Ohio, the most commonly used method is discussion ( $\mathrm{f}$ $=21$ ). The same methods are used in both countries but show similarities and differences due to differences in the implementation of techniques and understanding of education. While there is a narrative-based practice in Turkey, there is an active learning-based approach in Ohio. Some of the teachers' views on this theme are presented below:

"Probably the greatest technique used in values education is interactions between children and the teacher or among children. Every day, situations arise that allow teachers and children to discuss and reflect on certain values, such as compassion and responsibility." (OK2)

"Yeah, we're role models. We ask questions to understand them. These questions are generally unclear. We ask open-ended questions and make them come up with an idea." (OK10) 


\section{Findings Regarding Changes in Students}

According to the opinions of the pre-school teachers, the themes obtained regarding the changes observed in students in values education practices are shown in Table 6.

Table 6. Changes Observed in Students During the Process of Values Education

\begin{tabular}{llll}
\hline Turkey & $\mathrm{f}$ & Ohio & $\mathrm{f}$ \\
\hline Greatly changing & 14 & Being more organized and careful & 16 \\
Varies according to student's potential & 12 & More and longer focusing & 13 \\
Increased awareness & 8 & $\begin{array}{l}\text { Developing close friendships and establishing } \\
\text { deep bonds }\end{array}$ & 11 \\
Some small positive changes & 6 & Being peaceful & 9 \\
I observed no change & 3 & Making meaningful bonding with teacher & 9 \\
& Increasing curiosity and interest & 7 \\
& Empathy development & 6 \\
& Satisfaction with their situation & 6 \\
& Being confident about what they want to do & 5 \\
& Self-responsibility & 5 \\
& Resolving conflicts with a positive attitude & 3 \\
& Expressing themselves in a correct and positive & 2 \\
\hline
\end{tabular}

Changes observed in students as a result of practices related to values in the classroom differ between the two countries in terms of teacher views. Turkish teachers emphasized that these changes are positive and can vary from student to student. Some teachers emphasized the process while others stated that they did not observe any changes. Teachers stated all of the observed changes in general phrases, such as, "vary according to the student's potential", "their awareness increases", "some small positive changes."

"...varies from child to child. The difference determines the children's potentials. Although I approach evenly, the capacity and perception of each student is different." (TK24)

In Ohio, teachers identified the changes observed and linked these changes to behaviors. Being more organized and careful $(f=16)$ was the most observed behavior according to the teachers' opinions. Some of the changes observed under themes are more and longer focusing, being peaceful, developing close friendship relationships and deep bonds, meaningful bonding with the teacher, increasing curiosity and interest. Below are some of the views of teachers:

"I observe that the children are more organized and careful. I observe that they are more focused and confident and peaceful. They can also focus on a longer term and establish deep and important bonds with their classmates to become close friends." (OK8)

"That's what we've been waiting for. I see a lot of such changes. I see that what we call Peace Rose in our class is less used. You know, this is a symbol that we call peace. It's kind of like a traditional Pipe of Peace. If the children experience a contradiction, they go and take this rose and talk, now that we see that the rose is less visible. Because children need less reminder things to use this speech stick. So, if they're in a contradiction, rather than taking a break and going to get the rose, they're going to take care of that contradiction right there and in time" (OK26) 


\section{Findings Regarding Evaluation}

In the study, teachers' opinions about the methods of evaluating the values education process were asked. The findings are presented in Table 7.

Table 7. Methods of Evaluating Using in Values Education

\begin{tabular}{llll}
\hline Turkey & $\mathrm{f}$ & Ohio & $\mathrm{f}$ \\
\hline Question-answer & 20 & Observation & 23 \\
Observation and development report & 18 & Note-taking & 17 \\
Chat & 7 & Family conferences & 11 \\
Painting & 6 & Peer review & 10 \\
Feedback from families & 6 & Parent evaluation & 10 \\
& & DECA (The Devereux Early Childhood & 9 \\
& Assessment) & 7 \\
& Portfolio & Monthly target portfolio & 7 \\
& Discipline of consciousness & 6 \\
& Family bulletins & ASQ (Ages \& Stages Questionnaire, Age and & 5 \\
& Stage Surveys) & 4 \\
\hline
\end{tabular}

Evaluation methods of the teachers participating in the research from Turkey can be listed as question-answer, observation and development reports, chat with the students, students' paintings, and feedback from parents. On the other hand, the teachers who participated in the research from Ohio stated the methods they use as observation, note taking, family conferences, peer review, parent evaluation, The Devereux Early Childhood Assessment Program (DECA), portfolio, monthly target portfolio, conscious discipline, family bulletins, Ages \& Stages Questionnaire (ASQ), and process evaluation. Some of the teachers' views on this theme are presented below:

"There are noticeable changes in student behavior. I measure these changes with the student observation files that I hold at the beginning of the semester." (TK3)

"After asking open-ended questions about what you would do about the activities we do, I do free painting activities and I want them to explain the pictures they made. I write what they tell behind their pictures." (TK20)

"We use an assessment tool called DECA, which looks at the child's social and emotional development." (OK4)

"We keep notes that we call anecdote notes. So, we record and continue to record many things they do in class. We also keep examples of some of the things we work with. For example, if we see any improvement after writing, we keep a record of it. We also observe them socially. We also observe how this change and development is going. At the beginning of the year, we take notes of who they are, with whom they make friends, what kind of games they play, how they play these games, and we record these things to see similar changes." (OK18)

\section{Findings Related to Difficulties}

The themes obtained as a result of the analysis about the difficulties experienced by students as they acquire the values are shown in Table 8 . 
Table 8. Difficulties Encountered in Values Education

\begin{tabular}{llll}
\hline Turkey & f & Ohio & f \\
\hline $\begin{array}{l}\text { Inability to embody values / Students } \\
\text { do not understand abstract concepts }\end{array}$ & 19 & Social differences & 13 \\
$\begin{array}{l}\text { Workload of paperwork-procedure } \\
\text { False behavior learned in the family }\end{array}$ & 16 & Cultural differences and beliefs & 11 \\
$\begin{array}{l}\text { Families being unaware of preschool } \\
\text { education }\end{array}$ & 8 & Family values differ from school goals & 9 \\
$\begin{array}{l}\text { Lack of cooperation between families } \\
\text { Cultural differences and beliefs }\end{array}$ & 7 & & 7 \\
Resistance to change & 5 & & \\
$\begin{array}{l}\text { Past traumas experienced by children } \\
\text { Bad examples of media and }\end{array}$ & 4 & & \\
environment & 4 & & \\
Lack of resources to attract children's & 3 & & \\
interest & & \\
Administrator rules / prohibitions & 1 & & \\
\hline
\end{tabular}

According to the views of the Turkish participants, the difficulties experienced in values acquisition vary in comparison with Ohio. Inability to embody values $(f=19)$ was found to be the most experienced difficulty in the study. Many of the difficulties for students to gain values are related to family. The others can be listed as the workload of paperwork / procedure, cultural differences and beliefs, children's resistance to change and past traumas they experienced, bad examples in the media and the environment, lack of resources to attract children's interest and administrator rules / prohibitions.

"They're negatively affected by families. For example, I sometimes come across children who think that women should not work." (TK2)

"In general, universal and national values are abstract concepts. Since children are in a concrete process, it is often more difficult to explain, and since children of this age are generally more inclined to act impulsively, they cannot remember the rules and values they have learned during the activity." (TK17)

The teachers from Ohio, on the other hand, stated these difficulties as social differences, cultural differences and beliefs, family values being different from the goals of the school, and individual differences. Below are examples of teachers' views.

"Sometimes there are very difficult periods. We have children from various groups here. There are children with very different backgrounds. I'm talking about social differences. As you know, there are people with different income levels and children from many different countries, so there are children with many different family values. Many are adapting, but some want to apply what they see on TV, which is a bit tiring." (OK11)

"Families must be on board with the children. Some parents expect our center to be more academically based." (OK8)

\section{Findings Related to Suggestions to Develop Values Education Practices}

The themes obtained from the opinions of pre-school teachers towards the development of values education practices are presented in Table 9. 
Table 9. Teachers' Suggestions for Developing Values Education Practices

\begin{tabular}{|c|c|c|c|}
\hline Turkey & $\mathrm{f}$ & Ohio & $\mathrm{f}$ \\
\hline Parent training & 15 & $\begin{array}{l}\text { More time for students' social and emotional } \\
\text { development }\end{array}$ & 12 \\
\hline School-family-teacher cooperation & 9 & $\begin{array}{l}\text { More research and finding ways to be more } \\
\text { effective }\end{array}$ & 10 \\
\hline $\begin{array}{l}\text { Competence of the educational } \\
\text { environment }\end{array}$ & 8 & $\begin{array}{l}\text { More education and training cooperation for } \\
\text { teachers }\end{array}$ & 10 \\
\hline Qualified guide publications & 6 & $\begin{array}{l}\text { Correction of errors observed in existing } \\
\text { applications }\end{array}$ & 8 \\
\hline $\begin{array}{l}\text { Theater, drama or children's films } \\
\text { suitable for children }\end{array}$ & 5 & $\begin{array}{l}\text { Education of schools for social and emotional } \\
\text { health of children }\end{array}$ & 7 \\
\hline More value education in the program & 5 & Families' empowerment program & 6 \\
\hline Guidance forms for teachers & 4 & Development of the discipline of consciousness & 5 \\
\hline
\end{tabular}

In the context of suggestions for strengthening the applications of values education, most of the teachers participating from Turkey emphasize parental education $(f=15)$. Other themes that teachers have mentioned are: School-family-teacher cooperation, competence of educational environment, qualified guide publications, theater, drama or films suitable for children, more value education in the program and guidance forms for teachers.

"For kindergarten teachers, MoNE should define a common plan and the content should be guiding. The number of children in a classroom should be 15 so that we can carry out our values education in an appropriate environment. To act according to the child, the age group in the class must be the same. Having a 48-month-old child and a 60-month-old child in the same class-their perceptions are different, so the activities must be different, unfortunately I cannot do it." (TK7)

"Common social values can be prioritized, and the values where all segments of society meet at a common point can be given more place in the program. Activities with family participation can be organized in order to reach a unity of behavior with the concerning families." (TK15)

Teachers from Ohio, on the other hand, propose spending more time on students' social and emotional development, finding ways to do more research and being more effective, collaborating for more education and training for teachers, correcting mistakes observed in existing practices, reforming schools to target social and emotional health and wellbeing of children, an "empowering parents" program and development of the discipline of consciousness. Here are some excerpts from teachers' views:

"We've joined a new program called Empowering Families, which requires talking to more families. The most important objective of this program is to prevent child abuse. It is a program that aims to make families stronger." (OK18)

"The results of the most recent research should be shared. Training activities such as trainings in which colleagues share their experiences, different and exemplary teaching practices can be organized. Difficulties of the existing applications need to be identified and resolved." (OK5)

\section{Discussion}

In the context of values education while teachers who participated in the research from Turkey give priority to patriotism, national unity and solidarity, Kemalism and cultural values, the teachers who participated in Ohio give priority to autonomy, social rules, respect and kindness as national values. What is noteworthy here is that, unlike Turkish teachers, 
Ohio teachers place the autonomy and social life rules first. According to them, personal responsibility, self-control, skills to cope with difficulties and social rules in society are more important than patriotism for students in early childhood. This can be explained with that individuals who know their responsibilities and rules of social life, who do their job well and who are respectful and tolerant towards each other will be good citizens and therefore will value their homeland and people living in that country. In Turkey, patriotism and national and religious rituals are important elements in the society. These national values are processed not only in pre-school, but in all education programs in the country. However, these values should not be reduced to pure patriotism. National values should be included in education programs not only as the love of homeland but also with other features (Veyis, 2018). Therefore, it should be ensured that children internalize these values together with other values and become good citizens.

Universal values based on the views of teachers from Turkey were listed as respect, love, peace, tolerance, co-operation. According to the views of the participating teachers in Ohio, respect took the first place among universal values, while other values include courtesy, peace, justice and equality. These results are similar to many studies in the literature (e.g., Eskew, 2004; Kohn, 1997; Kozikoğlu, 2018; Pekdoğan \& Korkmaz, 2017; Ogelman \& Sarıkaya, 2015; Slater, 2008; Uzun \& Köse, 2017; Yazar \& Erkuş, 2013). In most of the studies carried out on the subject, values such as love, respect, tolerance, honesty, and sharing take the first place. Many countries have received values education in their curricula. When the values of these countries are examined, it is seen that values such as truth, love, freedom, equality, justice, respect for oneself and others, responsibility and being peaceful are common (Doğanay, 2007). Universal values and countries' common values are largely parallel. However, it is not enough to teach these values theoretically; individuals should be able to demonstrate the necessary knowledge, skills and attitudes that they can use in daily life (Fixler, 2000). Therefore, in addition to the values that need to be taught, it is of great importance to plan what kind of approaches teachers need to follow in passing on values to new generations.

In the research, teachers were asked about their opinions about the content and activities in the lessons. According to the results of the analysis, the opinions of the teachers of both countries are similar. While the content for pre-school values education in Turkey is based on pre-school education programs, in Ohio the content regarding values education is carried out according to common standards set by the state. The activities organized in the classes can be listed as special days and weeks, arts, music and games activities respectively. Uzun and Köse (2017) found in their studies that pre-school teachers included activities such as language, drama, music, art and play in the content of values education. Kozikoğlu (2018) argues that although values education is included in the pre-school education program, concrete activities for values education are insufficient and that the practices for values education are left to the initiative of teachers. In addition, the teachers in his study stated that the values education activities in the pre-school education program should be supported with out-of-school activities and game activities. Yazar and Erkuş (2013) also found that pre-school teachers organize the content according to the activities in the curriculum, but in the curriculum these values are classified only for some purposes of the social and emotional fields and many of the aspects of the activities such as which activities are to be implemented in what way and at what time, are left to the teachers. Lickona (2001), referring to a program in Baltimore, stated that teachers train individuals who are beneficial to society by using values which contains twenty-one ethical values such as compassion, honesty, justice, respect for others, responsible citizenship, judicial process and rule of law. According to these results, it can be said that 
there are content editing activities for values education in pre-school education programs, but they can be diversified in terms of facilitating teachers' work.

According to the opinions of teachers who participated in the research in Turkey, the methods used in the values education can be listed as discourse, discussion, case studies, demonstration, problem solving and learning activities outside the classroom. The same methods are used in both countries, but the application of techniques shows similarities and differences due to differences in educational understanding. While there are teacher-centered techniques in Turkey, there is an active learning-based approach in Ohio. Thompson (2011) found that teachers mostly preferred storytelling and role model techniques in values education. Akto and Akto (2017) determined that pre-school teachers use methods and techniques such as educational games, reading books, question-answer, drama and discussion in values education. The methods and techniques that can be employed in values education may vary according to teachers' practices. Student-centered practices such as book or story reading, educational play, drama, discussion, and art activities can be used effectively in values education (Chaitanya, 2017). Therefore, it is a positive result that teachers use different methods and techniques in values education. However, Turkish teachers should focus on other methods and techniques beyond narrative techniques that will make the student more active.

Changes observed in students as a result of practices related to the values applied in classes vary between the two countries according to the opinions of teachers. Turkish teachers considered these changes as positive and emphasized that these changes can vary among students. Some teachers emphasized the process while others stated that they do not observe any changes.

In Ohio, teachers identified the changes observed and linked these changes to specific behaviors. Accordingly, the changes observed in student behaviors were stated as being more organized and careful, more and longer focusing, being peaceful, developing close friendship relationships and deep bonds, meaningful bonding with the teacher, increasing curiosity and interest. Studies related to the subject state that values education in early childhood has positive effects on children. Trout (2008), in the study examining the effects of values education on children in the pre-school period, found that children five years of age and under had higher scores in understanding, recognizing, and converting values compared to children who were educated before the program existed. Öztürk-Samur (2011) concluded that the values education program applied to pre-school children positively supports children's social emotional development. This result of changes observed in the study stems from the differences in how teachers evaluate values education activities and observe their students.

Another theme related to the changes observed in the research is the evaluation methods of teachers. According to the results of the analysis, the assessment methods of Turkish teachers were listed as question-answer, observation and development report, chat with the students, painting and the feedback of families. Teachers in Ohio mostly preferred observation and taking notes about students. They also reported that they used family evaluation forms such as family conferences, peer and parent evaluation, portfolio and DECA-ASQ. These results show that Ohio teachers use a wider range of assessment methods than Turkish teachers and, as seen in the results of the previous theme, they can better observe their students' development and changes in behavior. It can be said that this is due to the fact that undergraduate education given is not enriched in terms of methods-techniques in preschool context or teachers have difficulty in applying these methods and techniques during real education processes. In addition, the fact that preschool programs in Turkey do not contain a 
variety of activities that will guide teachers as well as in Ohio can be considered as one of the factors that cause this situation. According to the views of the Turkish participants, the difficulties experienced in value acquisition vary. These are: not being able to embody values, leaving teachers alone with procedural paperwork instead of doing their job in the classroom, negative family attitudes, families being unaware of pre-school education, lack of cooperation and support from families, cultural differences and beliefs, children's resistance to change, children's past traumas and bad examples in the environment. The teachers from Ohio, on the other hand, stated their difficulties as social differences, cultural differences and beliefs, family values' being different from the goals of the school and individual differences. These results obtained in the study coincide with the results of many studies. Uzun and Köse (2017) concluded that pre-school teachers generally had difficulty instilling values because of the fact that values were abstract concepts for students, that these values could not be embodied, and that some values were above the cognitive level of the students. Kozikoglu (2018) listed teachers' problems as: The lack of family support in values education, lack of materials, difficulty in developing activities, difficulties in learning due to embodying values, differences in children's cognitive and developmental characteristics and problems caused by physical inadequacy of the school. Ogelman and Sarıkaya (2015), on the other hand, stated these difficulties experienced by teachers during their values education practices as: Short attention span of children, lack of abstract thinking and situations related to the level of readiness, lack of support expected from families, deficiencies about related activities, book and the program and lack of time. Yazar and Erkuş (2013) also determined that the issues that teachers have in values education are problems related to the teaching-learning process, high number of students, and problems related to family, teacher and environment. In line with the results of this study and similar studies in the literature, it can be said that preschool teachers have difficulties mostly in concretizing the values, getting full family support, dealing with children who have differing cognitive and developmental characteristics, and facing a lack of program and physical opportunities, and negative effects of the environment in values education. An important conclusion regarding this theme is that Ohio teachers do not experience as many problems as Turkish teachers or they do not complain about the problems they face. Most of the problems they report are due to social, cultural and individual differences. This may be a sign that teachers in Ohio are solution-oriented rather than problem-oriented.

In the context of making suggestions for strengthening the applications of values education, it has been concluded that Turkish teachers generally emphasize parental training, schoolparent-teacher cooperation, enhancing the educational environment and diversification of materials and activities. Teachers in Ohio recommend: More time for students' social and emotional development, more research and finding ways to be more effective, more education and training cooperation for teachers, correcting mistakes observed in existing practices for social and emotional health of children, reforming schools to target social and emotional health and wellbeing of children, family strengthening program and improvement of the discipline of consciousness

Parallel to the results of this study, in many studies in the literature it was found that raising awareness of families with education, seminarsand alike and continuity of cooperation with the family are very important in pre-school values education (Crowther, 1995; Fixler, 2000; Oktay, 1999; Pekdogan \& Korkmaz, 2017; Sapsağlam 2016a; Reynolds et al., 2011; Thompson, 2011; Yazar \& Erkuş, 2013). Apart from these, in the relevant literature there are various suggestions like including such activities such as making values education more fun and concrete with games, drama, and with other activities focusing on values education in 
pre-school education programs, enriching the materials and resources related to values education, providing opportunities to reach them, providing in-service trainings for teachers by values education experts, increasing out-of-school activities and trips, and preparing children according to their developmental and cognitive characteristics and cultural characteristics of the society (Doğan Temur \& Yuvac1 2014; Eskew, 2004; Kozikoğlu, 2018; Lickona, 2001; Ogelman \& Sarıkaya, 2015; Tarkoçin, Berktaş \& Uyanık Balat, 2013; Uzun \& Köse, 2017).

\section{Conclusion and Recommendations}

When the results of the research are evaluated in general, it can be seen that there are significant differences in the values education practices of the teachers of the two countries and many factors are effective in the transfer of values. The results show that values education cannot be provided only through the integration of values in the curriculum, and that value transfer is a sophisticated process involving many disciplines. Examples include culture, environment, family-school collaboration, and the ability of teachers to work in coordination with each other and with school management. The findings indicate significant differences in value perception as well as differences in practice in the two countries. For example, the priority national values were found to be different between Turkey and the U.S. In the U.S. (Ohio), autonomy, social life rules and respect stand out as the first three values, while in Turkey, patriotism, national unity and solidarity (Kemalism) rise as the first three values. Although there are similarities in the methods and techniques used in values education practices in both countries, it was concluded that in terms of assessment methods, teachers in Ohio are able to employ more diverse methods and observe their students better. In addition, Ohio teachers do not experience as many problems as Turkish teachers and are solutionoriented in values education practices.

In line with the results of the research and the suggestions of teachers for the development of practices, the following suggestions can be made for the implementation of values education in pre-school education:

- Teacher behavior plays a key role in the development of affective skills within a child's values domain. Therefore, establishing common standards in pre-school education in Turkey for teacher qualifications, and children's multi-faceted development for the education of cognitive, psychomotor and affective domains should be given equal importance.

- In values education, measures can be taken to increase teacher and parent cooperation, such as family participation. Trainings can be organized to raise the awareness of families.

- Considering that values are abstract concepts and difficult to acquire in this age group, concrete experiences can be included in both in-school and out-of-school activities in the programs.

- In the pre-school education program, concrete and fun activities in accordance with the development and cognitive characteristics of children about values education can be increased.

- Trainings and seminars on values education can be organized for pre-school teachers.

For further research: Research can be conducted with different working groups, including administrators, academicians and parents. Comparative research involving schools in different socio-economic environments can be conducted. Studies using different data collection tools 
such as observation and researcher diaries can be organized. The relationship between perceptions of values with different variables such as age, gender, socio-economic level and developmental areas such as social, cognitive and physical can be examined.

\section{Acknowledgments}

This study is part of a project supported by TÜBİTAK (1059B191600044).

\section{References}

Acat, M. B., \& Aslan, M. (2010, September). Character education and character education applications in the World. Paper Presented at the 19th Education Sciences Congress. Lefkoșe, Cyprus.

ACEV, (2007). "7 is too late” Campaign. Retrieved from https://www.acev.org/wpcontent/uploads/2019/10/2007-faaliyetraporueng.pdf

Akbaş, O. (2009). Activities carreed out by branch teachers working in primary schools while teaching values: A comparison of the years 2004 and 2007. Kastamonu Education Journal, 17(2), 403-414.

Akto, A., \& Akto, S. (2017). Methods and techniques used in pre-school values education (a qualitative research). Journal of Oriental Scientific Research, 9(2), 1074-1095. doi: 10.26791/sarkiat.342143

Aral, N., Kandır, A., \& Can Yaşar, M. (2003). Okul öncesi eğitim 1 [Preschool education 1 ]. (2nd ed.). İstanbul: Ya-Pa Publishing.

Aspin, D. N. (2000). Values, beliefs and attitudes in education: The nature of values and their place and promotion in schools. Education, Culture and Values, 14, 197-218.

Balat, G. U., \& Dağal, A. B. (2009). Okul öncesi dönemde değerler eğitimi etkinlikleri [Values education activities in preschool period]. Ankara: Kök Publishing.

Başal, H. A. (2012). Gelişim ve psikoloji-nasıl mutlu bir çocuk yetiştirebilirim [Development and psychology-how can I raise a happy child]. Bursa: Ekin Kitabevi Publishing.

Chaitanya, M. (2017). Value based education and methods, strategies, approaches to impart it in education. International Journal of Research Culture Society, 1(5), 6-10.

Cihan, N. (2014). Values education at schools and its practice in Turkey. Electronic Turkish Studies, 9(2), 429-436.

Cooper, D. (2014). Character education: a study of an elementary school leadership academy. Wilmington University (Delaware).

Creswell, J. W. (2007). Qualitative inquiry \& research design: Choosing among five approaches ( 2 nd ed.). USA: SAGE Publications.

Crowther, E. (1995). An independent school library-classroom-parent pertnership program to encourage respect, responsibility, courtesy, and caring for prekindergarten through $\begin{array}{lllll}\text { eighth } & \text { grade. } & E D & \text { Retrieved } & \end{array}$ https://files.eric.ed.gov/fulltext/ED388964.pdf

Dewey, J. (2013). The school and society and the child and the curriculum. University of Chicago Press.

Doğan Temur, Ö. \& Yuvac1, Z. (2014). Examining the main values concepts and activities acquired at pre-school education institutions providing pre-school values education. Amasya Education Journal, 3(1), 122-149.

Doğanay, A. (2007). Değerler eğitimi [Values education]. In C. Öztürk (Ed.), Hayat bilgisi ve sosyal bilgiler ögretimi yapılandırmacı bir yaklaşım [A constructivist approach to life science and social studies teaching] (pp. 255-286). Ankara: Pegem Akademi Press. 
Early Childhood Ohio (2017). Ohio's early childhood system. Retrieved from http://www.earlychildhoodohio.org/Ohios-EarlyChildhoodSystem.stm

Egeland, B., Yates, T., Appleyard, K., \& Van Dulmen, M. (2002). The long-term consequences of maltreatment in the early years: A developmental pathway model to antisocial behavior. Children's services: Social policy, research, and practice, 5(4), 249-260. doi: 10.1207/S15326918CS0504_2

Erden, M. (1998). Öğretmenlik mesleğine giriş [Introduction to teaching]. İstanbul: Alkım Publishing.

Eskew, D. S. (2004). Values education in American public schools: An overview with implications for the future. (Doctoral dissertation). University of Georgia.

Fixler, B. (2000). A caring and sharing environment helps teach values kindergarten students, ED 445781. Retrieved from https://files.eric.ed.gov/fulltext/ED445781.pdf.

Gömleksiz, M. N. (2007). Lise öğrencilerinin toplumsal değerlere ilişkin tutumları: Elazığ ili örneği [Attitudes of high school students towards social values: The case of Elazlğ province]. In Kaymakcan, S. Kenan, H. Hökelekli, Z. Ş. Arslan, M. Zengin (Eds.) Değerler ve eğitimi [Values and education] (pp. 727-741). İstanbul: Values Education Center Publishing.

Halstead, J. M., \& Taylor, J. M. (2000). Learning and teaching about values: a review of recent research. Cambridge Journal of Education, 30(2), 169-202.

Halstead, J.M., \& Pike, M. A. (2006). Citizenship and moral education: Values in action. Cornwall: Routledge.

Hildebrandt, C., \& Zan, B. (2014). Constructivist approaches to moral education in early childhood. In L. P. Nucci \& P. Narvaez (Eds.) Handbook of moral and character education (pp. 196-213). New York: Routledge.

Katranc1, M (2014). Okul öncesi eğitim ve önemi [Preschool education and its importance]. In S. Seven (Ed.), Okul öncesi eğitime giriş [Introduction to Preschool Education] (pp. 2-14). Ankara: Pegem Akademi Press.

Kirschenbaum, H. (2000). From values clarification to character education: a personal journey. Journal of Humanistic Counseling, Education \& Development, 39(1), 4-17.

Kohlberg, L. (1971). Stages of moral development. Moral Education, 1(51), 23-92.

Kohn, A. (1997). How not to teach values: A critical look at character education. Phi Delta Kappan, 78, 429-439.

Lickona, T. (2001). What is good character? Reclaiming Children and Youth, 9, 234-238.

Melhuish, E. C. (2011). Preschool matters. Science, 333(6040), 299-300. doi: 10.1126/science. 1209459

Ministry of National Education (MNE), (2013). Republic of Turkey Ministry of National Education, early childhood curriculum. Retrieved from https://tegm.meb.gov.tr/dosya/okuloncesi/ooproram.pdf

National Association for the Education of Young Children (NAEYC), (2009). NAEYC standards for early childhood professional preparation. Retrieved from https://www.naeyc.org/sites/default/files/globallyshared/downloads/PDFs/resources/p ositionstatements/2009\%20Professional\%20Prep\%20stdsRevised\%204_12.pdf

Ogelman, G. H., \& Sarıkaya, E. H. (2015). Views of preschool teachers about education of values: Case of Denizli province. Sakarya University Journal of Education Faculty, 29, 81-100.

Ohio Department of Education, (2017). Birth through kindergarten entry implementation guides. Retrieved from http://education.ohio.gov/Topics/Early-Learning/EarlyLearning-Content-Standards/Birth-Through-Pre_K-Learning-and-DevelopmentStand/Birth-Through-Pre_K-Implementation-Guides 
Oktay, A. (1999). Yaşamın sihirli yılları: Okul öncesi dönem [The magic years of life: Preschool]. İstanbul: Epsilon Press.

Organisation for Economic Cooperation and Development (OECD), (2017). Starting strong v: Transitions from earlychildhood education and care to primary education. Paris: OECD Publishing. Retrieved from http://dx.doi.org/10.1787/9789264276253-en.

Öztürk-Samur, A. (2011). The impact of the values education program on the social and emotional development of children aged 6 years. (Doctoral dissertation). Selçuk University, Social Sciences Institute.

Pagani, L. S., Jalbert, J., \& Girard, A. (2005). Does preschool enrichment of precursors to arithmetic influence intuitive knowledge of number in low income children? Early Childhood Education Journal, 34(2), 134-146.

Pekdoğan, S., \& Korkmaz, H. İ. (2017). The examination of teachers' view concerning values education for 5-6 year old preschoolers. Mustafa Kemal University Journal of Social Sciences Institute, 14(37), 59-72.

Piaget, J. (2002). Judgement and reasoning in the child. Routledge.

Reynolds, A. J., Temple, J. A., Ou, S. R., Arteaga, I. A., \& White, B. A. (2011). School-based early childhood education and age-28 well-being: Effects by timing, dosage, and subgroups. Science, 333(6040), 360-364. doi: 10.1126/science.1203618

Rokeach M., \& Regan J. F. (1980). The role of values in the counseling situation. The Personnel and Guidance Journal 58( 9), 576-582.

Ryan, K., Bohlin, K. E., \& McDonnell, S. N. (1999). Building character in schools: Practical ways to bring moral instruction to life. San Francisco: Jossey-Bass.

Sapsağlam, Ö. (2016a). Okul öncesi dönemde karakter ve değerler eğitimi: Teoriden uygulamaya [Character and values education in preschool period: From theory to practice]. Ankara: Pegem Akademi Press.

Sapsağlam, Ö. (2016b). Examination of targets in preschool education programs in terms of values. Electronic Turkish Studies, 11(9). 683-700. doi:10.7827/TurkishStudies.9571

Schwartz, S. H., Caprara, G. V., \& Vecchione, M. (2010). Basic personal values, core political values, and voting: A longitudinal analysis. Political psychology, 31(3), 421452.

Slater, R. O. (2008). American teachers: What values do they hold?. Education Next, 8(1), 46-52.

Şen, M. (2011). Okul öncesi dönem değerler eğitiminde öğretmenin ve okulun rolü [Role of teacher and school in pre-school values education]. In A. Arıkan (Ed.), Okul öncesi dönemde değerler eğitimi [Values education in preschool period] (123-147). Eskişehir: Anadolu University Publishing No:2301.

Tarkoçin, S., Berktaş, D., \& Uyanık Balat, G. (2013). An investigation into the values of the communication which is used in classroom activities by teachers. Pegem Journal of Education \& Instruction, 3(2), 37-49.

Thompson, M. (2011). Developing moral values in children: observations from a preschool. Ife PsychologIA: An International Journal, 19(2), 394-411.

Titus, D. N. (1994). Value education in American secondary schools. ED 381423. Retrieved from http://www.hi-ho.ne.jp/taku77/refer/titus.htm

Trout, N. J. (2008). Building chracter education in the preschool. (Doctoral dissertation). Capella University.

Ural, O., \& Ramazan, O. (2007). Türkiye'de okul öncesi eğitimin dünü ve bugünü. Türkiye'de okul öncesi eğitim ve ilkögretim sistemi temel sorunlar ve çözüm önerileri [Yesterday and today's pre-school education in Turkey. Pre-school and primary education system in Turkey, the main problems and solutions]. Türk Eğitim Derneği. ISBN, 978, 99445128. 
Uzun, M., \& Köse, A. (2017). Teachers' Opinions about the application of values education during preschool education. Journal of Bayburt Education Faculty, 12(23), 305-338.

Veugelers, W., \& Vedder, P. (2003). Values in teaching. Teachers and Teaching, 9(4), 377389. doi: 10.1080/1354060032000097262

Veyis, F. (2018). The place of Turkish language and literature schoolbooks in national values transferring: An analyze on actual books. Journal of National Education, 48(221), 141-157.

Walker, H. M., \& Golly, A. (1999). Developing behavioral alternatives for antisocial children at the point of school entry. The Clearing House, 73(2), 104-106.

Walker, S., Brownlee, J., Whiteford, C., Cobb-Moore, C., Johansson, E., Ailwood, J. \& G. Boulton-Lewis (2012). Early years teachers' epistemic beliefs and beliefs about children's moral learning. Teachers and Teaching, 18(2), 263-275. doi: 10.1080/13540602.2012.632267

Weist, L. R. (1998). Using immersion to shake up pre-service teachers' views about cultural differences. Journal of Teacher Education, 49(5), 358-365.

Yavuzer, H. (2012). Doğum öncesinden ergenlik sonuna çocuk psikolojisi [Child psychology from prenatal to puberty]. İstanbul: Remzi Publishing.

Yazar, T., \& Erkuş, S. (2013). The evaluation the opinions of pre-school education teachers about the values education in pre-school education programme. Dicle University Journal of Ziya Gökalp Education Faculty, 20, 196-211.

Yeşil, R., \& Aydın, D. (2007). The method and timing in democratic values education. Journal of TSA, 11(2), 65-84.

Y1ldirım, K. (2009). Values education experiences of Turkish class teachers: A phenomonological approach. Eurasian Journal of Educational Research, 35, 165-184.

Yin, R. K. (2017). Case study research and applications: Design and methods. Sage publications. 